\title{
Apropiaciones historiográficas en la dramaturgia argentina de la posdictadura: los casos Raúl Dargoltz y Juan Raúl Rithner
}

\section{Historiographic Appropriations in the Argentine Post-dictatorship Dramaturgy: the Raúl Dargoltz and Juan Raúl Rithner Cases}

Artículo recibido el I2 de abril de 2020; devuelto para revisión el 26 de octubre de 2020; aceptado el I8 de noviembre de 2020; https://doi.org/IO.2220I/iie.I8703062e.202I.II9.2764

Mauricio Tossi Universidad Argentina de la Empresa (UADE)/Consejo Nacional de Investigaciones Científicas y Técnicas (Conicet), mauriciotossi@gmail. com, https://orcid.org/oooo-oooI-5I44-2544

Líneas de investigación Historia y teoría del teatro argentino.

Lines of research History and theory of the Argentine drama.

Publicación más relevante "Figuras autoficcionales de la 'memoria herida' en la dramaturgia argentina posdictatorial”, Letral. Revista Electrónica de Estudios Transatlánticos de Literatura, núm. 23 (2020): 89-117.

Resumen En el contexto de la posdictadura argentina, las dramaturgias de la Patagonia y el noroeste han actualizado el potencial estético del teatro histórico moderno, mediante una particular relectura del teatro documental. Así, determinadas obras de Raúl Dargoltz y Juan Raúl Rithner exponen modos específicos de apropiación de referentes historiográficos del norte y el sur del país. A pesar de sus fronteras geográficas, estas dramaturgias evidencian una solidaridad poética entre ambas regiones, al optar por la resignificación de procedimientos estéticos que, entre otros efectos, contribuyen al abordaje de interrogantes comunitarios sobre los sentidos del pasado reciente.

Palabras clave Teatro documental; referentes historiográficos; dramaturgias comparadas; estudios interregionales; posdictadura argentina; noroeste; Patagonia.

Abstract In the context of the Argentine post-dictatorship, the dramaturgies of Patagonia and the Northwest have updated the aesthetic potential of modern historical theater, through a particular rereading of documentary theater. Thus, certain plays by Raúl Dargoltz and Juan Raúl Rithner expose specific ways of appropriating historiographic references 
from the north and south of the country. Despite their geographical borders, these dramaturgies show a poetic solidarity between both regions, by opting for the resignification of aesthetic procedures that, among other effects, contribute to addressing community questions about the meanings of the recent past.

Keywords Documentary theatre; historiographic references; compared dramas; interregional studies; Argentine post-dictatorship; Northwest; Patagonia. 
DOI: https://doi.org/10.22201/iie.18703062e.2021.119.2764

\author{
MAURICIO TOSSI \\ UADE/CONICET
}

\title{
Apropiaciones historiográficas en la dramaturgia argentina de la posdictadura:
}

los casos Raúl Dargoltz y Juan Raúl Rithner

$\mathrm{E}$

n un esquema de país centralista y con legados culturales homogeneizantes, las dramaturgias de la Patagonia y del noroeste argentinos (I983I997) ${ }^{1}$ develan múltiples configuraciones identitarias que aportan a una descentralización de los procesos estéticos. Por razones metodológicas, este artículo acota su indagación a un eje particular de estudio: las apropiaciones historiográficas que, en el marco de la posdictadura, ${ }^{2}$ instauran en los textos teatrales regionales una determinada red poética y construyen diálogos con específicas representaciones sociales del tiempo pasado.

I. Estas regiones están integradas por las siguientes provincias: a) noroeste: Jujuy, Salta, Tucumán, Catamarca y Santiago del Estero; b) Patagonia: La Pampa, Río Negro, Neuquén, Chubut, Santa Cruz y Tierra del Fuego. Estas circunscripciones zonales operan en este trabajo como base conceptual por ser, fundamentalmente, el mapeado que rige en las políticas y debates culturales de la posdictadura, es decir, desde la reapertura democrática en 1983 hasta 1997, fecha en la que se sanciona la Ley 24.800 o Ley Nacional del Teatro, la cual modifica los modos de producción de los campos teatrales provinciales.

2. Este término remite a una modalidad de representación cultural, dinámica y plural, sobre el tiempo pasado reciente, con proyecciones macro y micropolíticas contemporáneas. Vale decir, no se alude a una periodización cronológica cerrada. Véase Jorge Dubatti, "El teatro argentino en la posdictadura: 1983-2002”, Los Rabdomantes, núm. 3 (2003): 35-49. 


\section{DOI: https://doi.org/10.22201/iie.18703062e.2021.119.2764}

332

MAURICIO TOSSI

En efecto, el trabajo de archivo realizado muestra una concluyente tendencia hacia la intertextualidad e interdiscursividad historiográfica en la composición de las estructuras ficcionales de las dramaturgias del norte y sur del país. Estas evidencias se asocian con una singular tradición artística: el teatro histórico. Esta poética ha ocupado un espacio relevante en el pensamiento/ creación de los teatros regionales argentinos, tal como lo expresa - por ejemplo- uno de los intelectuales más importantes de las letras norteñas: Bernardo Canal Feijóo (1897-1982).

Puntualmente, en 1962, el mencionado historiador, poeta y dramaturgo santiagueño escribe el artículo titulado "Historia y teatro", en el que se cristaliza uno de los interrogantes estéticos que signará — de manera implícita—a las indagaciones dramatúrgicas de los distintos campos escénicos del país. Desde mi punto de vista, este ensayo teórico es un eslabón operativo y estratégico para indagar en las genealogías y "macropoéticas" interregionales vinculadas con el drama histórico.

La relación entre teatro e historia la aborda Canal Feijóo desde dos ángulos distintos: por un lado, las formas dramáticas que buscan en la historia sus contenidos; por otro, la historia como promotora de acciones teatrales. Mediante este esquema de reciprocidades, el autor inscribe el arte teatral de fases paradigmáticas en directa vinculación con el tiempo histórico, siendo la forma poética de la tragedia el continente de dispositivos escénicos dominantes. Por ejemplo, resultan sugestivas sus lecturas e interpretaciones comparadas entre los modelos de dramaturgia griega e isabelina, pues, señala: "La verdadera genialidad de Shakespeare consiste en haber sustituido la mitología por la historia en la concepción de la tragedia. [...] Lo que los griegos encontraban cifrado en su mitología, Shakespeare lo encuentra —o busca - en la historia". ${ }^{4}$ De este modo, el teatro de diversas épocas —-mediante los cánones griegos o isabelinos— ha suscitado una específica relación con las fuentes, ya sean míticas o propiamente historiográficas.

Este particular diálogo entre las formas dramáticas y el tratamiento de las "fuentes", según las concepciones e intencionalidades temporales a ellas atribuidas, le permite a Canal Feijóo aseverar una singular tesis, dice:

3. Según Dubatti, una macropoética es un constructo poético relacional, elaborado como un conjunto de micropoéticas (o individuos textuales) que se vinculan entre sí mediante invariables o constantes. Véase Jorge Dubatti, El teatro jeroglifico. Herramientas de poética teatral (Buenos Aires: Atuel, 2002), 59.

4. Bernardo Canal Feijóo, "Historia y teatro", Revista del Instituto Nacional de Estudios de Teatro, t. II, núm. 5 (1962): 6. 


\section{DOI: https://doi.org/10.22201/iie.18703062e.2021.119.2764}

APROPIACIONES HISTORIOGRÁFICAS DE LA DRAMATURGIA

La elección del tema histórico prescinde de la lejanía o proximidad en el tiempo del pretexto anecdótico elegido; puede tratarse de un suceso remoto o de un hecho del pasado inmediato. La cuestión depende de la posibilidad de captar a través de un hecho, cierta perspectiva particular dentro de la perspectiva cronológica general.

Al seguir los estudios de Georg Wilhelm Hegel y Georg Simmel respecto de la tragedia, el dramaturgo norteño localiza uno de los fundamentos de valor de la archipoética del teatro histórico, esto es, un singular tratamiento estético o estilización de un referente con el objeto de "captar" lo sincrónico-particular en lo diacrónico-universal.

Con estos aportes, Canal Feijóo forma parte de un sistema de pensamiento que, entre otras cualidades, ha exhortado a la valoración identitaria y geocultural de las prácticas artístico-regionales; es decir, sus posicionamientos sobre el teatro y la historia integran un locus de enunciación diferencial que confronta con las tradiciones homogeneizadoras o reduccionistas aplicadas a las estéticas de las provincias u otras "periferias" de la nación argentina.

En correlación con los estudios de Canal Feijóo, el investigador Juan Villegas ha definido el teatro histórico en América Latina como un específico discurso de apropiación del tiempo pasado, sin embargo, esta relectura de referentes historiográficos no tiene por objeto la "reconstrucción" de lo histórico narrado sino la construcción de un "pasado funcional" a los basamentos ideológicos de los productores del discurso. ${ }^{6}$ Así, el discurso teatral histórico o, simplemente, el "teatro histórico" crea — mediante códigos de teatralidad e historicidad legitimados en un localizado campo cultural - un determinado "imaginario social", cuyas tareas pueden ser la ratificación de un sistema cultural o la desconstrucción del orden dominante. ${ }^{7}$

En suma, el citado investigador — sin una intertextualidad directa con Canal Feijóo- expone cuatro formas estructurales del teatro histórico y, a su vez, cuatro procedimientos centrales en la elaboración de este singular discurso teatral. En relación con las formas poético-referenciales que el teatro histórico

5. Canal Feijóo, "Historia y teatro", 6.

6. Juan Villegas, "El teatro histórico latinoamericano como discurso e instrumento de apropiación de la historia", en Teatro histórico (1975-1998). Textos y representaciones. Actas del VIII Seminario Internacional del Instituto de Semiótica Literaria, Teatral y Nuevas Tecnologias de la UNED, eds. José Romera Castillo y Francisco Gutiérrez Carbajo (Madrid: Visor Libros, 1999), 233.

7. Villegas, "El teatro histórico latinoamericano", 235. 


\section{DOI: https://doi.org/10.22201/iie.18703062e.2021.119.2764}

puede adoptar, Villegas reconoce: las composiciones escénicas tradicionalistas, sustentadas en la "historia oficial"; el teatro documental; las creaciones dramáticas que poseen como referente el testimonio directo del autor o del colectivo que lo produce, es decir, "el presente histórico del productor, el que, con el tiempo, se transformará en discurso histórico"; 8 el teatro autobiográfico, esto es, la puesta en evidencia de un relato de vida (real o ficticio) de los personajes.

Paralelamente a estas formas estructurales, Villegas propone - en su interpretación de un contexto posmoderno latinoamericano- los siguientes procedimientos o mecanismos de apropiación de lo histórico-referencial, a saber:

Uno de ellos es considerar la "historia" como un mito; otro es enfatizar la conciencia de la historia como "escritura" y su deconstrucción; un tercero es considerar los factores determinantes de la "memoria histórica"; y el cuatro se refiere a la representación degradada de las grandes narrativas históricas, es decir aquellas que han buscado explicar la totalidad del sentido de la historia. ${ }^{9}$

De las formas y estrategias poético-históricas descritas por Canal Feijóo y Villegas, delimitaré para este estudio la corriente denominada "teatro documental”, esto último — insisto— - según el locus de enunciación diferencial que esta modalidad dramatúrgica ha alcanzado en la Patagonia y el noroeste argentinos durante la posdictadura.

El teatro documental o docudrama se desarrolló en los campos culturales de América Latina desde finales de la década de los años sesenta, como una variante del teatro histórico-realista. En ese marco, el ensayo teórico "Notas sobre el teatro-documento", de Peter Weiss ${ }^{10}$ operó como un texto "faro" para los intelectuales comprometidos de la escena latinoamericanista, con lineamientos que pueden sintetizarse en los siguientes aspectos:

- El teatro-documento es un teatro de información con apelaciones reflexivas, expresado en múltiples huellas históricas (actas, cartas, cuadros estadísticos, entrevistas, fotografías, etc.) que se exponen sin variación de

8. Villegas, "El teatro histórico latinoamericano", 239.

9. Villegas, "El teatro histórico latinoamericano", 245.

Io. Peter Weiss, "Notas sobre el teatro-documento", en Escritos politicos (Barcelona: Lumen, 1976), 97-IIO. 
contenido y se seleccionan con el fin de analizar un tema específico desde una perspectiva materialista.

- El docudrama tiene por función develar la "falsa conciencia" sostenida en los discursos dominantes, ya sean, periodísticos, económicos, religiosos o histórico-oficiales; es decir, esta forma escénica tiene por meta desnudar los ideologemas y las tácticas de los sectores hegemónicos, al revelar sus lógicas de poder estructural.

- El teatro documental renuncia a la función inventiva para dar lugar a la verdad histórica de los hechos empíricamente comprobables, pero no renuncia a experimentar en la potencialidad artística que emerge de lo "real/documentado", pues — según Weiss - su eficacia política se consolida en la fuerza estética de la obra. Ante la fragmentación de una realidad compleja y dispersa, este teatro asume como técnica el montaje de dichos fragmentos, pero por medio de un tajante ejercicio crítico y partidista, al exponer las pruebas a dictamen del espectador, explicar las causas y consecuencias del fenómeno y, finalmente, al proyectar una tesis sobre el tema, la que implica una evidente toma de posición frente a la conflictividad social abordada.

En función de los aportes estéticos de Weiss y de los desarrollos dramatúrgicos posteriores, la autora Silka Freire ha realizado un exhaustivo análisis del docudrama latinoamericano, objetivado en la actualización de tres núcleos operativos del acontecimiento teatral: lo comunicacional, lo temporal y lo referencial. ${ }^{\text {II }}$ Respecto de este último núcleo, estratégico para el cumplimiento de nuestro propósito, Freire afirma:

En el caso particular del docudrama, la permanente apelación a lo contextual, conformado en este caso por el referente histórico, designa situaciones, personajes y objetos que, por su inevitable pertenencia a un extratexto plenamente identificado por los receptores, permite la creación de un universo discursivo seudo-ficcional, donde la ficcionalidad se origina en la hábil disposición de mecanismos recreativos de diversos centros temáticos que tienen un aval histórico y, por lo tanto, el reconocimiento público de haber sucedido $[\ldots] .^{12}$

II. Silka Freire, Teatro documental latinoamericano: el referente histórico y su (re)escritura dramática (La Plata: Al Margen, 2007), 49.

I2. Freire, "Teatro documental latinoamericano", 84. Las cursivas son de la autora. 


\section{DOI: https://doi.org/10.22201/iie.18703062e.2021.119.2764}

En efecto, para Freire la experiencia estética que un docudrama promueve se funda, entre otros mecanismos, en el ejercicio de una "contratextualidad", ${ }^{13}$ dado que el referente de esta forma escénica admite una prueba empírico-contrastiva, generada por los diversos y heterogéneos aparatos textuales y discursivos que la componen. Así, los dispositivos de percepción e interpretación que el teatro documental gestiona inducen a la "resemantización" de los documentos historiográficos citados y/o referenciados.

A partir de esta urdimbre conceptual y sus asimilaciones regionales, acoto la presente indagación al siguiente objeto/problema: en el contexto de reestructuración de un nuevo sujeto democrático (1983-1997), ¿qué referentes historiográficos son apropiados y resemantizados ${ }^{14}$ en el teatro de la Patagonia y del noroeste argentinos? En términos comparativos, ¿qué procedimientos poéticos del docudrama los autores de ambos campos escénicos — distantes y periféricos- han resignificado en su lectura del "tiempo pasado" reciente?

Para avanzar sobre estas interrogaciones abordaré el estudio de dos casos estratégicos, los textos Hacha y quebracho (1984) de Raúl Dargoltz y El Maruchito. Sangre y encubrimiento alli en las tierras del viento (1997), de Juan Raúl Rithner. La selección de estas piezas responde a dos criterios funcionales: primero, se inscriben en la apertura y en el cierre de la fase histórica demarcada, y generan un arco temporal que encubre a otras creaciones teatrales de referencia; segundo, ambos casos adscriben y despliegan recursos estéticos que permiten problematizar y comparar la regionalización poética del docudrama en las zonas norte y sur del país. ${ }^{15}$

I3. Freire, "Teatro documental latinoamericano", 85-86.

I4. Tal como demostraré más adelante, la noción de resemantización alude a las múltiples reanimaciones hermenéuticas (actualizaciones, transformaciones barrocas, analogías, entre otros) de referentes historiográficos que, en los singulares contextos del norte y sur argentinos, se incorporan a las dramaturgias seleccionadas.

I5. Otro fundamento para la selección de estas dos piezas dramatúrgicas remite a los escasos y asistemáticos estudios críticos registrados sobre estos autores. En relación con la obra de Dargoltz, el principal análisis histórico-textual hallado es el trabajo de Nelly Tamer, quien en un capítulo de libro periodiza su producción teatral en tres fases y, a su vez, resume los principales lineamientos estéticos de su obra, aunque sin desarrollar un examen exhaustivo de sus creaciones textuales ni una indagación poética particularizada. Respecto de las obras de Rithner, a la fecha no han sido relevadas ni analizadas de manera integral, pues sólo se encuentran comentarios parciales en una ponencia escrita por Perla Zayas de Lima y un análisis textual de su dramaturgia infantil en un artículo de Mauricio Tossi. Para conocer estas fuentes, véase: Nelly Tamer, "Una aproximación al teatro socio-político de Raúl Dargoltz", en La Quila. Cuaderno 


\section{DOI: https://doi.org/10.22201/iie.18703062e.2021.119.2764}

APROPIACIONES HISTORIOGRÁFICAS DE LA DRAMATURGIA

\section{Hacha y quebracho de Raúl Dargoltz: la contratextualidad historiográfica}

La producción artística y científica de Raúl Dargoltz ${ }^{16}$ ha revisitado de manera sistemática las creaciones intelectuales de escritores que, según su perspectiva, consolidan un pensamiento nacional autónomo y resisten a los embates colonizadores. Entre otros referentes de sus indagaciones hallamos a Raúl Scalabrini Ortiz, Arturo Jauretche, Orestes Di Lullo y, en especial, los aportes de su coprovinciano, el ya citado Bernardo Canal Feijóo.

En efecto, Feijóo y Dargoltz son grilletes de un mismo linaje dramatúrgico, el que - independientemente de sus notorias diferencias estéticas y/o procedimentales - se cristaliza en el noroeste argentino mediante lo que Zulma Palermo denomina "regionalismo crítico", es decir, su identificación o familiaridad no se sustancia en una territorialidad folclórica, lengua o raza, sino por la puesta en funcionamiento de una genealogía alternativa, en la que predominan los silenciamientos marginados y los entrecruzamientos fronterizos. ${ }^{17}$ Para ambos escritores, la provincia de Santiago del Estero — una de las

de historia del teatro, núm. 2, comp. Mauricio Tossi (Viedma: Universidad Nacional de Río Negro, 20I2), 22I-24I; Perla Zayas de Lima, "El teatro y sus posibles transferencias en diversas áreas sociales. A propósito de Aldo Grasso y Raúl Rithner", en Los dramaturgos/as del interior del país. Actas de las Terceras Jornadas, comp. Marta Lena Paz (Buenos Aires: Universidad de Buenos Aires-Instituto de Artes del Espectáculo, 1998), I27-I34; Mauricio Tossi, "La aldea de Refasí: el teatro infantil rionegrino en la reapertura democrática", Argus-a. Artes \& Humanidades, núm. I2 (2014): I-I9.

I6. Raúl Dargoltz (1945-2009). Abogado y maestro en Estudios Sociales, dramaturgo y director teatral. Se desempeñó como investigador adjunto del Conicet y profesor regular en la Universidad Nacional de Santiago del Estero. Sus producciones escénicas incluyen la escritura de Hacha y quebracho —nombre que dio origen a su grupo teatral en 1984-, La politica de la Chinche Flaca, Clemencia, I love Argentina, Todos los abogados van al cielo, Amerindia, El santiagueñazo, El enemigo del pueblo, El hijo de Santiago, entre otras. Por las mencionadas obras teatrales, recibió múltiples premios, los que surgen de manera paralela a las distinciones otorgadas por sus libros teóricos y ensayos científicos, a saber: Hacha y quebracho fue premiada y seleccionada para representar a la provincia de Santiago del Estero en el Festival Nacional de Teatro 1985, además, ganó el Primer Premio en el Concurso Nacional de las Artes y las Ciencias (Argentina, 1985), Premio Coyoacán (México, 1990) y la distinción honorífica de la Universidad Nacional de Bogotá (1989), entre otras menciones otorgadas durante sus giras internacionales por América Latina y Europa.

17. Zulma Palermo, “¿Por qué vincular la literatura comparada con la interculturalidad?”, en Lindes actuales de la literatura comparada, ed. Adriana Crolla (Santa Fe: Universidad Nacional del Litoral, 20II), I26-I27. 


\section{DOI: https://doi.org/10.22201/iie.18703062e.2021.119.2764}

reconocibles periferias norteñas- es un "centro" estratégico, en el que se forman, debaten y contrastan determinadas alteridades. Esos "otros" olvidados, los caídos de cartografías y tiempos hegemónicos son la materialidad referencial de sus piezas teatrales y ensayos teóricos. En suma, tal como señala Palermo, Feijóo y Dargoltz comparten un proyecto de autodefiniciones y transformaciones de los esquemas de pensamientos "totalizadores", al proponer un "criterio semiótico" ${ }^{18}$ alternativo para vivir, conocer y habitar lo circundante, sin caer en instancias de homogeneización cultural.

Así, podemos correlacionar la dramaturgia de Dargoltz con los dos lineamientos establecidos por Feijóo en su concepción teatral: por un lado, la provocadora frontera entre las formas teatrales que buscan en la historia sus contenidos y la historiografía como promotora de acciones escénicas; por otro lado, los ensambles sincrónicos y diacrónicos, vale decir, "captar a través de un hecho, cierta perspectiva particular dentro de la perspectiva cronológica general". ${ }^{19}$

Hacha y quebracho se estrenó en 1984, en la ciudad de La Banda, provincia de Santiago del Estero, con las actuaciones de Juan Carlos Almada y Daniel Nassif; este último artista tuvo a su cargo, además, la dirección general del montaje. Hasta 2009 se realizaron diversas puestas en escena de esta obra, con reactualizaciones y adaptaciones efectuadas y aprobadas por Raúl Dargoltz. ${ }^{20}$ Los actores Darío Dante “Tito” Díaz, Juan Zarazaga, Daniel Centeno, José "Machi" Kairuz y el director Rafael Nofal son, entre otros, los agentes escénicos que consolidaron este largo proceso artístico, expresado en centenares de representaciones teatrales en los ámbitos nacional e internacional.

Los devenires de este texto teatral emergen y convergen en un hipotexto historiográfico que operó como catalizador de sus distintas instancias escénicas, me refiero al libro Santiago del Estero: el drama de una provincia, editado en $1980,{ }^{21}$ reeditado en $1985^{22}$ y en I99I, aunque en esta última oportunidad

I8. Palermo, “¿Por qué vincular la literatura comparada con la interculturalidad?”, I27.

19. Canal Feijóo, "Historia y teatro", 6.

20. Para este análisis, tomaré como referencia la edición del texto teatral de Hacha y quebracho publicado en 1996 y, además, una actualización textual e inédita del director Rafael Nofal, con complementos del montaje escénico coordinado por él en I99I.

2I. Raúl Dargoltz, Santiago del Estero: el drama de una provincia (Buenos Aires: Castañeda, 1980).

22. Raúl Dargoltz, Santiago del Estero: el drama de una provincia (Buenos Aires: Ediciones Del Mar Dulce, 1985). 
con el título Hacha y quebracho. ${ }^{23}$ Por consiguiente, se establece una recíproca y fértil vinculación entre los postulados historiográficos plasmados en las distintas reediciones y las versiones o modificaciones escénico-procedimentales experimentadas durante los 25 años de montajes escénicos. En otros términos, las matrices teórico-sociológicas elaboradas por Dargoltz se solidifican en un artefacto artístico dinámico, permanentemente historizado: el docudrama Hacha y quebracho, cuya titulación opera, además, como un ideologema de síntesis entre el discurso historiográfico y el discurso teatral, observable en la reedición del ensayo teórico en I99I. De este modo, en la dramaturgia de Dargoltz el vínculo entre historia y teatro remite al "juego sinérgico" propuesto por Canal Feijóo para el "nivel de historia", esto es, una doble relación entre factores naturales (la tierra y sus paisajes diferenciales, junto con los condicionantes productivos, étnicos y demográficos) y artificiales (rasgos técnicos asociados con lo político-económico, las vías de comunicación, la jurisprudencia, los reactivos estéticos o artísticos, entre otros). ${ }^{24}$ En esta genealogía anidan las proposiciones de un regionalismo que, entre otras cualidades, exige una singular dialéctica entre geografía e intersubjetividad, entre conocimientos metódicos y conocimientos poéticos.

Para demostrar estas interdiscursividades nos proponemos a continuación analizar la apropiación y resemantización escénica de los núcleos historiográficos que convergen en la estructura textual y en la organización ficcional de Hacha y quebracho.

En función de esta perspectiva de estudio, hallamos como "fundamento de valor" ${ }^{25}$ la ratificación de la tesis historiográfica y sociológica elaborada en el ensayo teórico citado, la que expone los basamentos de la pauperización estructural de la provincia de Santiago del Estero y la consecuente consignación de sus habitantes como parias, condenados a la trashumancia por los principales centros demográficos. En el prólogo a la reedición de 1991, el autor señala al respecto:

23. Raúl Dargoltz, Hacha y quebracho. Santiago del Estero: el drama de una provincia (Santiago del Estero: Ediciones Conciencia Nacional, 1991).

24. Bernardo Canal Feijóo, "Nivel de historia y otras proposiciones", en Ensayos, ed. Leonor Arias Saravia (Buenos Aires: La Crujía, 20I0), 7I-84.

25. Al considerar los diversos niveles de producción de sentido de una dramaturgia, Dubatti propone reconocer un "núcleo fundante" en el que se construye una determinada manera de comprender y habitar el mundo textualizado. Véase Dubatti, El teatro jeroglifico. Herramientas de poética teatral, 65. 


\section{DOI: https://doi.org/10.22201/iie.18703062e.2021.119.2764}

Y he notado, con tristeza, que las viejas y nuevas generaciones iniciamos el aprendizaje de una realidad circundante de una manera totalmente deformada y antojadiza. Elaborada, juntamente, por aquellos que desean que la verdadera historia de nuestro pueblo permanezca en las sombras. Son los mismos personajes que esperan que sigamos siendo la provincia "pobre", con mayor porcentaje de éxodo de sus habitantes; la fuente inacabada del servicio doméstico de la Capital Federal; los mejores cultores del folclore y los cuentistas inimitables, únicos capaces de reírnos de nuestra propia pobreza y de la triste e injusta forma de falta de apego al trabajo. ${ }^{26}$

Por ende, Dargoltz transpone su tesis histórico-sociológica en una tesis poético-realista, con base en los procedimientos del docudrama. De manera puntual, esta simetría entre discurso académico y discurso teatral se funda en cinco núcleos histórico-diegéticos: a) la debacle de la industria azucarera en la provincia; b) el fracaso de los innovadores proyectos de navegación del río Salado, con el objetivo de construir una vía de conexión económica y político-cultural entre Bolivia, Paraguay y el litoral Atlántico; c) el trazado del ferrocarril en plena tensión con el proyecto naval anterior y con el interés hegemónico del capital inglés; d) la explotación forestal del quebracho, con ominosas consecuencias locales; e) la entrega de tierras públicas y, en suma, la configuración de una otredad dominante en la región santiagueña: "la tierra sin hombres".

A partir de estos cinco núcleos histórico-diegéticos el autor compone — desde nuestra visión hermenéutica- I4 "secuencias dramáticas", ${ }^{27}$ contenidas y estructuradas en cinco cuadros textuales que, por ser tales, poseen una relativa autonomía ficcional. Por sus aires de familia con los recursos de la epicidad brechtiana, la pieza afianza su dramaturgia al recurrir a un procedimiento central: la desnaturalización de determinados fenómenos sociopolíticos y económicos del norte argentino durante el siglo XIX y su correlativa contrastación con un presente plagado de pasado; vale decir, se apela a un proceso que -en términos formales - se vincula con el efecto de extrañamiento de la poética del autor alemán. El quiebre de lo "naturalizado" se ejerce, en este caso, mediante

26. Dargoltz, Hacha y quebracho. Santiago del Estero: el drama de una provincia, 9-Io.

27. Se entiende por situación dramática a la constelación de fuerzas actanciales que concierne a la relación entre los personajes en un "estado" o en una fase temporal específica, lo que - a su vez- promueve el devenir dramático. Véase José Luis García Barrientos, Cómo se comenta una obra de teatro. Ensayo de método (Ciudad de México: Paso de Gato, 2013), 86. 
la "contratextualidad historiográfica", un recurso modélico del docudrama que Dargoltz puede traducir escénicamente a partir de su investigación científica. La contratextualidad historiográfica como procedimiento poético central en la dramaturgia de Hacha y quebracho se evidencia desde el inicio del relato, conjugado por medio de componentes visuales y musicales que dialogan entre sí. Por ejemplo, en las dos primeras secuencias dramáticas se observa la proyección de imágenes en diapositivas de diversas fases temporales de la vida socioeconómica de Santiago del Estero y su contrasentido en la canción/narración "Uniremos la voz", musicalizada en vivo por uno de los actores. El mencionado tema musical actúa como isotopía argumental a lo largo de la obra. La canción dice:

Santiago, tierra que cantas cuando sufres / la dulzura de tu azúcar se perdió tras la madera de tus bosques. / Con el bosque se fue también, la esperanza de tus hombres $[\ldots]$

El quebrachal, en las hachas murió, / su verde corazón de madera y dolor. Selvas americanas enlazadas de amor / donde fue mi raíz una sola canción.

Selvas americanas, abrigadas de sol / un mañana vendrá y uniremos la voz. ${ }^{28}$

En este marco introductorio, la obra desarrolla el primer cuadro, un híbrido textual por la fusión de elementos ficcionales y autobiográficos, en tanto se enmarca a la escena en un festival de folclor - parodia de los reconocidos certámenes santiagueños - con la representación de un locutor y un cantante, ambos interpretados en nombre propio por los actores Dante "Tito" Díaz y José "Machi" Kairuz, ${ }^{29}$ en este caso, actuantes/personajes. Sin abandonar estos incipientes atributos autoficcionales, la pieza entrelaza nuevas canciones con cuentos o chistes populares, los que exponen una identidad cristalizada y, por tanto, esencialista del santiagueño, esto es: un ser vago, inscrito en una pereza continua y condicionada por el calor incesante de la zona desértica, un ciudadano pobre y sin horizontes o programas futuros. Estos sedimentos identitarios son contrastados por las imágenes de las diapositivas que muestran a sus conciudadanos en medio de desgarradoras inundaciones, o en situaciones de explotación como hacheros, albañiles, artesanos, cesteras, entre otros múl-

28. Raúl Dargoltz, Hacha y quebracho, comp. Rafael Nofal (Santiago del Estero: inédito, cedido por el autor, 2009), 4 .

29. Los nombres propios cambian, lógicamente, según el elenco que los represente. En este caso, sigo los datos de la edición de 1996. 


\section{DOI: https://doi.org/10.22201/iie.18703062e.2021.119.2764}

tiples rubros que forman parte del patrimonio laboral regional y que, claro está, contradicen la cristalización anterior. La deconstrucción de esta alteridad esencialista, entendida como uno de los posibles "otros" de la "nación interior" — tal como lo designa Beatriz Ocampo- ${ }^{30}$ será el punto de ataque discursivo que el docudrama escrito por Dargoltz intentará denunciar, contrastar y refutar.

Este proceso de denuncia, contrastación y refutación de una otredad homogeneizante inicia en las secuencias dramáticas número tres, cuatro y cinco, por medio de los paralelismos entre el ensayo historiográfico-sociológico de referencia y la correspondiente traducción escénica. Esta simetría asume en ambos relatos una misma lógica argumentativa, íntimamente ligada a los núcleos histórico-diegéticos arriba mencionados. En primer lugar, la obra expone y representa las desavenencias políticas del explorador español Esteban Rams y Rupert —denominado por el escritor Miguel Cané como "un Colón de tierra adentro"- y el baqueano Lino Belbey durante el proyecto de navegación del río Salado, el cual buscó conectar las redes fluviales del Gran Chaco-Santiagueño con determinadas regiones de la Puna norteña y zonas del litoral; es decir, en el marco de los ideales federales del siglo XIX, se intentó crear en Santiago del Estero un conducto social y comercial sin precedentes hasta nuestros días. Este plan obtuvo, tal como lo demuestra Dargoltz en sus investigaciones, un incipiente apoyo del gobernador Taboada y de la Confederación —incluso de Juan Bautista Alberdi, en su papel de embajador en Europa - hasta que, en el marco de los intereses económicos de ese periodo, surgen los intervencionismos y las presiones de los capitales ingleses, al imponer el ingreso de los ferrocarriles como forma hegemónica de comunicación.

De este modo, Dargoltz ratifica las críticas a los modelos "civilizatorios" de los programas colonizadores del siglo XIX y, a la vez, construye un efecto de sentido sobre el presente histórico del espectador, en particular, sobre las transformaciones coyunturales de las economías regionales en el contexto de la posdictadura argentina iniciada en 1984, luego del fracaso de los programas neoliberales de la fase dictatorial (1976-1983).

La secuencia dramática número seis se ocupa de otro pionero o referente de una contracultura civilizatoria en la provincia: el francés Pedro Saint Germes, esto es, un nuevo antecedente historiográfico que le permite al autor consolidar sus argumentos sociológicos y documentar las acciones/narraciones de

30. Beatriz Ocampo, La nación interior. Canal Feijóo, Di Lullo y los Hermanos Wagner (Buenos Aires: Antropofagia, 2004). 
los personajes teatrales. La figura de Saint Germes es representada por Dargoltz con diversos atributos románticos, evidenciados en la utópica creación de la industria azucarera en Santiago del Estero, una manufactura descentrada, sin precedentes y con pésimos diagnósticos. No obstante, el tesón y el cariz modernizador del protagonista le permiten fundar el primer ingenio local. Los esquemas de sobreproducción, el agobio del mercado interno y el retiro del apoyo del Estado, nuevamente, vinculado con los intereses extranjeros asociados con la instauración del ferrocarril provocan la muerte lenta de la industria y del propio Saint Germes, quien —en correlación con los aspectos románticos antes señalados - se suicida arrojándose al trapiche fundador de su ingenio.

En suma, las seis primeras secuencias dramáticas que estructuran el texto y su orden ficcional resultan equivalentes a la premisa "A" de la tesis a ratificar: las políticas para una modernización santiagueña, basada en la actividad azucarera y fluvial, fueron obturadas por interposiciones imperialistas y centralistas. Sin embargo, esta tesis requiere de premisas subsidiarias, también desarrolladas en el discurso académico y el discurso teatral que el autor contrasta en Hacha y quebracho. Por ende, el índice-temático de la historiografía social relatada y el nudo dramatúrgico de la obra teatral en estudio convergen en un mismo vector: la explotación forestal del quebracho, la cual — junto con la instalación del ferrocarril y los latifundios locales - opera como variable dominante en la ecuación que explica la indigencia y desertización de la provincia. El último cuadro de la obra, el que posee mayor extensión escénica y condensa las secuenciaciones dramáticas números siete a I4, se concentra en este vector-síntesis de la tesis.

A partir de los documentos y relatos de vida que integran el archivo elaborado para su ensayo teórico, Dargoltz expone un cariz representativo de las privaciones del peón santiagueño, según determinadas transformaciones políticas, dice:

Zenobio Campos, viejo obrero forestal domiciliado en Quimilí (Depto. Mariano Moreno), delegado de la Federación Obrera Santiagueña de la Industria Forestal (FOsıF) desde el año I949, nos decía desentrañando viejos recuerdos, que él se hizo "radical y de Irigoyen, porque fue en este gobierno que recién se empezó a sentir en la provincia el cumplimiento de leyes laborales, antes no existíamos, y después, me hice peronista por el mismo motivo". ${ }^{31}$

3I. Dargoltz, Santiago del Estero: el drama de una provincia, I24. 


\section{DOI: https://doi.org/10.22201/iie.18703062e.2021.119.2764}

344

MAURICIO TOSSI

Por su relevante función sindical y por sus singulares trayectos vitales, Zenobio Campos es un caso paradigmático en la comprensión de los procesos económico-sociales que el autor intenta dilucidar de manera conceptual y traducir de manera escénica. Sin embargo, siguiendo el procedimiento de la contratextualidad historiográfica, se debe indicar una particularidad: esta figura histórica no se estudia de manera exhaustiva en el texto científico, pues sólo se dice de él lo antes citado. En el texto académico Dargoltz no se explaya en estos singulares resultados etnográficos, empero, estos datos serán fuentes estético-creativas para ampliar, recrear y resemantizar la figura de Zenobio Campos en el texto teatral de Hacha y quebracho.

Desde esta perspectiva, se resignifica la decisión poética por la cual las situaciones dramáticas números siete, ocho, nueve, diez y once tiene como fuerza actancial dominante a Zenobio Campos. Es decir, se evidencia un sólido y certero ejercicio de complementariedad entre el relato historiográfico y el relato dramatúrgico, pues la fenomenología descrita por Dargoltz sólo puede leerse de manera integral o dialógica por medio de esta doble implicación y de la contrastación de ambos discursos.

Precisamente, lo que se testifica en el dispositivo teatral — no explicitado en el texto académico - es la trayectoria vital completa y generacional de Zenobio Campos. Este ciclo biográfico inicia en la secuencia número siete, allí el personaje — joven, ebrio y desahuciado — canta una copla popular sobre el padecimiento como destino irreversible del pobre. Su pesimismo se fundamenta en las condiciones de despojo y malaria en que vive junto con su familia, luego de radicarse - con promesas laborales incumplidas - en la zona de Quimilí para la explotación de los bosques de quebracho. En estas circunstancias agobiantes ha perdido a su hijo mayor, no tiene casa digna, agua potable ni comida suficiente para el resto de los suyos. Además, la queja o el reclamo por sus derechos sólo provocan mayores injusticias, por ejemplo: represalias salariales o, incluso, torturas en el cepo, esto último, por la falta de una legislación específica en esa industria y, fundamentalmente, por la connivencia entre el poder económico y el poder político locales. El reconocimiento de estas condiciones de vida ominosas es interpretado por el autor en los términos de una "esclavitud blanca" en el norte argentino, fundada en la indefensión ante los autoritarismos oligárquicos y en las injusticias típicas de los terruños aislados y "sin ley".

En esta instancia ficcional, la forma poética del teatro documental se sustancia con mayor objetividad procedimental, dado que las secuencias subsiguientes ratifican la convergencia entre la confianza comunicativa del discurso 
escénico, las referencias históricas y los ensamblajes crítico-ideológicos con un "tiempo presente" objeto de la tesis a contratextualizar. De este modo, los recursos utilizados poseen aires de familia con el "devenir rapsódico" ${ }^{32}$ descrito por Sarrazac en la dramaturgia contemporánea, al emparentar esta modalidad con el "hilvanado de cantos" del rapsoda medieval. El devenir rapsódico se inscribe entre lo dramático y lo épico por su tendencia al montaje o remiendo de fragmentos diegéticos híbridos. Este mosaico escritural — tal como dice el citado investigador francés - rechaza al "bello animal aristotélico" y, en sus desdoblamientos, funda un "caleidoscopio" modal. ${ }^{33}$

Hacha y quebracho se asemeja a la "rapsodización" por su capacidad de operar como una "ruta de contrabando" para la tensión, desborde o fuga de disímiles y opuestos modos discursivos, esto es, su solvencia lúdica en relación con lo narrativo-historiográfico, lo dramático-actoral, lo épico y lo autoficcional.

El rebase de estos procedimientos poéticos se observa en los siguientes componentes: primero, en las elipsis temporales que se registran en el pasaje de una secuencia a la otra que alteran las convencionales unidades de acción y tiempo dramáticas o, también, en la canción épica que redunda pedagógicamente en los aspectos bioidentitarios del obrero del quebracho santiagueño, dice:

La boca abierta del monte / te está esperando hachador.

Para morderte los sueńos / por orden de tu patrón.

Hacha tras hacha en el monte / tajo tras tajo el quebracho.

Golpe tras golpe del hacha / juntos al suelo nos vamos.

Golpe tras golpe del hacha / ay, juntos al suelo nos vamos. ${ }^{34}$

El mosaico de voces subjetivas y documentos probatorios se expone, además, en un segundo recurso: la "cita textual" de un testimonio histórico sobre la condición subalterna del peón en el obraje, sin paráfrasis mediante y literalmente incorporado el corpus del texto dramático, con un entrecomillado que alude a una referencialidad o prueba de veracidad implícita. En la secuencia dramática número ocho, cuando el personaje Patrón lee una carta dirigida al director de Trabajo de la Provincia, dice:

32. Jean-Pierre Sarrazac, Léxico del drama moderno y contemporáneo (Ciudad de México: Paso de Gato, 2013), I9I.

33. Sarrazac, Léxico del drama moderno y contemporáneo, 192.

34. Dargoltz, Hacha y quebracho, comp. Rafael Nofal, I9. 


\section{DOI: https://doi.org/10.22201/iie.18703062e.2021.119.2764}

346
MAURICIO TOSSI

Usted conoce señor Director lo que es el obrero santiagueño. Es un bohemio sin aspiraciones y muy inclinado al juego y al alcohol. Estos vicios lo dominan y como consecuencia de ello no tiene nunca dinero para atender a las necesidades propias y a las de su familia. Bien puede recibir $\$ 100$ o $\$ 200$ y mañana no tener ningún centavo. La ha gastado en bebidas, en prostitutas o en el juego. Y todo esto se lo procura aunque tenga que caminar cinco o seis leguas a pie para burlar la vigilancia severa que se ejerce en nuestro obraje en su beneficio. Así gasta siempre su anticipo que se denomina "alcance" y los salarios por varios meses. Por supuesto que de esta manera siempre está en deuda con nosotros. Señor Director, podemos asegurar que en general los industriales santiagueńos en lugar de ser victimarios como se los pinta somos verdaderas víctimas. Reconocemos que una buena parte del personal obrero santiagueńo es trabajador e inteligente y bueno. Con un poco de espíritu de ahorro y menos afición por el alcohol llegaría a un bienestar y a la independencia económica. Al obrero, en fin, es necesario que se le enseñe a conocer y a cumplir con su deber, antes que inducirlo a trabajar poco y a formular reclamaciones. El deber primero, el derecho después. ${ }^{35}$

Este documento historiográfico escenificado — proveniente del archivo del "Establecimiento Ottavia de Compagno Hermanos", fechado en 1928 - opera como prueba fehaciente sobre la otredad del jornalero del quebracho y, por su extensiva configuración social, sobre la otredad del "hombre sin tierra" presente en la definición geocultural del "país interior". Por tanto, la alteridad del asalariado de provincia como un "bohemio sin aspiraciones", un sujeto alcohólico y vicioso, tan irresponsable de sí mismo y de sus familias que — sí o sírequiere del paternalismo oligarca para ser útil y próspero en un sistema social "moderno", aunque no lo logrará y por ello estará en "deuda” permanente con sus generosos patrones, quienes con impunidad se ubican como "víctimas" y no "victimarios". Esta concepción del otro/interior — fundada en el "deber primero, el derecho después" - queda explícitamente documentada y verificada por medio de esta cita textual, al generar un efecto de espejo entre el discurso teatral y el texto sociológico de referencia.

Un tercer componente que cimienta la rapsodización procedimental en este docudrama es la hibridez de distintas tipologías de enunciados y de situaciones

35. Raúl Dargoltz, "Hacha y quebracho", en Teatro (Santiago del Estero: Conciencia Nacional, 1996), 63; Dargoltz, Hacha y quebracho. Santiago del Estero: el drama de una provincia, II5-II6. Las comillas son del autor. 


\section{DOI: https://doi.org/10.22201/iie.18703062e.2021.119.2764}

APROPIACIONES HISTORIOGRÁFICAS DE LA DRAMATURGIA

de enunciación. En efecto, las últimas cuatro secuencias dramáticas de Hacha y quebracho intensifican las relaciones escenotécnicas entre lo dicho y lo mostrado, al producir oscilaciones entre identificación y distanciamiento a partir de las imágenes y los contenidos presentados en las diapositivas, las canciones, los diálogos y monólogos, o en las exposiciones del narrador épico, representados por los actores que ejercen su presencia en la escena según códigos autoficcionales: uso del nombre propio para distinguirse de los personajes, referencias biográficas basadas en su profesión de artistas, indicadores de tiempo y lugar que coinciden con el espectador, etcétera.

Por consiguiente, la ficcionalización del ciclo vital de Zenobio Campos se irrumpe y "extraña" mediante "literalizaciones" ${ }^{36}$ brechtianas y docudramáticas. Es decir, el citado peón, quien finalmente rompe con la identidad esencialista mencionada, logra abandonar el obraje explotador del quebracho y acceder a una industria legalizada, en manos del empresario ruso-socialista Weisburd. En estas nuevas circunstancias laborales asumirá funciones sindicales y, como ya se dijo, ocupará un cargo central en la Federación Obrera Santiagueña de la Industria Forestal (FOSIF). Paralelamente a estas acciones ficcionales se producen los cortes por literalizaciones, planteados por el "Actor", en tanto narrador épico y autoficcional. Por ejemplo, en un fragmento dice:

Actor: Se quiso ocultar la larga noche de la explotación forestal. Santiago del Estero tenía a comienzos del siglo más de diez millones de hectáreas de bosque, en la actualidad sólo quedan setecientas mil. Más de nueve millones de hectáreas fueron irracionalmente explotadas. (Comienzan a aparecer las primeras diapositivas sobre la explotación forestal).

Ciento cincuenta millones de quebrachos colorados fueron destruidos, aparte del algarrobo blanco, negro y otras especies completamente diezmadas. Los bosques santiagueños proporcionaron durante más de treinta años toda la red ferroviaria nacional y más de doscientos millones de toneladas de madera, las que traducidas en moneda alcanzarían cifras astronómicas capaces de cubrir durante varios años el presupuesto nacional y pagar toda la deuda externa argentina [...] $\mathrm{Y}$

36. Esto es, según Benjamin, "lo figurado se mezcla con lo formulado", expresándose en la utilización de carteles, formulaciones narrativas y no dramáticas, títulos explícitos u otros recursos que desnudan a la escena de su "sensacionalismo temático". Véase Walter Benjamin, “Qué es el teatro épico?”, en Tentativas sobre Brecht. Iluminaciones III (Madrid: Taurus, 1999), 22-23. 


\section{DOI: https://doi.org/10.22201/iie.18703062e.2021.119.2764}

348 MAURICIO TOSSI

esta enorme riqueza nunca más volvió a la provincia. Hoy sólo queda éxodo, miseria y desocupación. ${ }^{37}$

Las alternancias entre secuencias ficcionales y narraciones épico-documentales progresa hasta el final del relato dramatúrgico, en el que se representa el declive económico y la expropiación de las empresas del grupo Weisburd, de manera correlativa con la debacle sociopolítica y económica de las industrias provinciales en el marco de las dictaduras autodenominadas "Revolución Argentina" (1966-1973) y "Proceso de Reorganización Nacional" (1976-1983), mediante apelaciones historiográficas a las gestiones de los ministros Krieger Vasena y Martínez de Hoz, respectivamente.

El ímpetu local por los proyectos de navegación del río Salado y Bermejo se retoman — según las fuentes del docudrama - en el marco de la reapertura democrática en 1984, aunque sin éxito alguno, pues estos proyectos vuelven a confrontar con los imperativos centralistas que revalidan la adscripción de Santiago del Estero a una territorialidad periférica y subyugada. No obstante la aseveración de esta tesis realista, la que condensa los resultados de una pauperización sistemática y estructural de la provincia, junto con los desequilibrios demográficos provocados por la trashumancia forzada y el consecuente destino aciago de miles de ciudadanos, surge en la secuencia dramática número I4 una "mirada final": $3^{8}$ la ficcionalización del personaje Maestro, uno de los hijos de Zenobio Campos, quien rechaza su traslado docente a la capital para quedarse en los poblados desérticos, es decir, en aquellos satélites sin centro, formados alrededor de una fábrica cerrada que, otrora, operaba como núcleo de la urbanidad y de las motivaciones sociales. El recurso de la "mirada final" se afianza en la última acción dramática, cuando los actores — sin signos de teatralidad- asumen su yo-biográfico de artistas en situación de representación escénica para confrontar con la mirada a los espectadores y afirmar: "Ésta es la verdad que nosotros le hemos entregado" ${ }^{39}$ Esta unidad cierra con la canción isotópica "Uniremos la voz", comentada en páginas anteriores.

37. Dargoltz, "Hacha y quebracho", 64.

38. Este recurso es, según Pellettieri, una regla obligatoria en el diseńo de intriga del realismo reflexivo argentino, una poética reapropiada por la dramaturgia realista de la región NOA. Su característica es la ratificación de la tesis abordada por medio de distintos formatos discursivos o textuales. Véase Osvaldo Pellettieri, Una historia interrumpida. Teatro argentino moderno (1949-1976) (Buenos Aires: Galerna, 1997), I20.

39. Dargoltz, "Hacha y quebracho", 7I. 


\section{DOI: https://doi.org/10.22201/iie.18703062e.2021.119.2764}

APROPIACIONES HISTORIOGRÁFICAS DE LA DRAMATURGIA

En la versión dramatúrgica compilada por uno de los directores teatrales del montaje de Hacha y quebracho, Rafael Nofal, el texto registra un segundo final o desenlace alternativo, escrito por el propio Dargoltz y escenificado por los actores Dante "Tito" Díaz y José "Machi” Kairuz en las representaciones de la obra llevadas a cabo en la década de 1990. Vale decir, la secuencia dramática número I4 se elimina completamente y, al finalizar la citada canción épica, el Actor — un yo ficcionalizado- expone:

¿Cuántos Zenobios Campos le hacen falta a Santiago? ¿Cuántos Zenobios Campos hay en las escuelas? ¿En las oficinas? ¿En los hospitales? ¿En las universidades? ¡Que no se mueran nunca los Zenobios Campos! ¡Hacha, Zenobio, puro filo de acero! ¡Quebracho, Zenobio, dura madera de mis bosques! ¡Espíritu de una raza indomable, espíritu de Santiago, espíritu de la Argentina, espíritu de Latinoamérica! iiCarajo!!+4

Con este cambio discursivo y representacional, la obra consolida su redundancia político-pedagógica, destinada a probar su tesis central, mediante la contratextualidad historiográfica que - a lo largo del montaje - un espectador "lugarizado" puede comprender estética e ideológicamente.

El Maruchito de Juan Raúl Rithner: la potencialidad del rodeo anacrónico

En 1997, en un difícil marco social, caracterizado por las movilizaciones y los reclamos populares resultantes de la "desertización" 4 económica causada por las políticas neoliberales en la Patagonia durante la década de los ańos noventa, Juan Raúl Rithner ${ }^{42}$ estrena su texto teatral El Maruchito. Sangre y encubri-

40. Dargoltz, Hacha y quebracho, comp. Rafael Nofal, 27.

4I. Para un desarrollo exhaustivo del marco social de aquellos años, véase: Ernesto Bohoslavsky, La Patagonia (de la guerra de Malvinas al final de la familia ypefiana) (Buenos Aires: Biblioteca Nacional y ungs, 2008).

42. Juan Raúl Rithner nació en Buenos Aires y se radicó en la ciudad de General Roca (Río Negro) en 1970. Se desempeńó como comunicador social, narrador, dramaturgo y docente universitario. Paralelamente a su labor como profesor/investigador y coordinador del Centro de Estudios Patagónicos de Comunicación y Cultura de la Universidad Nacional del Comahue, trabajó como periodista y director del Fondo Editorial Rionegrino. Entre sus cuentos infantiles y obras teatrales con reconocimiento nacional están: Nicolás y la sombra; El león y la aurora; 


\section{DOI: https://doi.org/10.22201/iie.18703062e.2021.119.2764}

350

MAURICIO TOSSI

miento allí en las tierras del viento, con puesta en escena del grupo Los Nosotros, perteneciente a la Cooperativa de Trabajo Artístico La Hormiga Circular de la ciudad de Villa Regina (Río Negro). El montaje estuvo a cargo del director Carlos Massolo, con las actuaciones de Magalí Reyes, Garza Bima, Juan Queupán, Sebastián Arzuaga, Adriana Bancalá, Silvia Alvarado y Alejandro Cabrera.

Esta obra posee aires de familia con el docudrama por su estructura textual, organización ficcional y dispositivos de referencialidad. Sin embargo, siguiendo las categorizaciones de Canal Feijóo, Villegas y Freire comentadas en páginas anteriores, esta pieza fusiona distintos mecanismos de apropiación de lo historiográfico, pues ensambla lo mítico con el discurso-documental de una conciencia histórica y su correlativa deconstrucción regional.

El procedimiento poético que le permite a Rithner configurar dramatúrgicamente estos diversos mecanismos de apropiación historiográfica es, de manera primordial, el "rodeo" ${ }^{33}$ inducido por la yuxtaposición anacrónica de "tiempos diegéticos". ${ }^{44}$ Entonces, si la referencialidad docudramática de Hacha y quebracho se estructura — según lo demostrado- a partir de la "contratextualidad", en El Maruchito los dispositivos referenciales se distancian del recurso realista, objetivista y cronológico de la contrastación para abrir un campo discursivo polivalente: la oblicuidad y el entrecruzamiento de tiempos pasados heterogéneos y discontinuos, aunque sin desestimar la operación bibliográfico-referencial que lo inscribe en la vertiente del teatro documental.

El anacronismo ha sido el peor error que un científico social puede cometer. No obstante, desde un cariz artístico, los discursos ficcionales (narrativa, teatro, cine) que han capitalizado para su acervo estético las fuentes documentales de tiempos discontinuos han demostrado su potencialidad gnoseológica en la construcción de discursos memorísticos. La obra El Maruchito

Desmesura de amor; Leyendas y creencias de la Patagonia; Y los pájaros seguirán cantando; La aldea de Refasi; $A$ balazos fue la cosa, entre otros. Por su producción literaria ha obtenido múltiples distinciones, entre las que destaca el Premio Nacional de Dramaturgia en el XX Encuentro Nacional de Escritores Patagónicos de 1997, por su obra El Maruchito. Sangre y encubrimiento, alli en las tierras del viento.

43. Jean-Pierre Sarrazac, Juego de sueño y otros rodeos. Alternativas a la fábula en la dramaturgia (Ciudad de México: Paso de Gato, 20II), 13-27. Este concepto será desarrollado posteriormente.

44. Esta noción remite al plano temporal de la fábula o el argumento, vale decir, es el tiempo ficcionalizado según el texto dramático. Véase García Barrientos, Cómo se comenta una obra de teatro. Ensayo de método, 96. 
ingresa a estas discusiones sobra la "pulsión referencial del relato histórico" 45 según sus propias coordenadas poético-regionales.

Desde este punto de vista, los aportes de Georges Didi-Huberman se tornan relevantes para nuestro trabajo, pues, recupera los conceptos benjaminianos de la imagen dialéctica para concebir a la imagen histórica no como un suceso o dispositivo estático del pasado, despojada de las múltiples condiciones del devenir; por el contrario, entiende a la imagen como portadora de memoria, dado que nunca deja de reconfigurarse con el paso del tiempo. ${ }^{46}$ En correlación con lo que él denomina el "hilo rojo" de esta visión epistémica, creada por Aby Warburg, Carl Einstein y el ya mencionado Walter Benjamin, propone analizar la historia de las imágenes como una historia de los objetos temporales impuros, complejos y sobredeterminados, es decir, asume una "heurística del anacronismo" ${ }^{47}$ que no responda —únicamente— a la idealización eucrónica (o tiempo concordante, factual y contextual). En este régimen teórico, el anacronismo no es un error de lectura del pasado, puesto que se convierte en un modo de comprensión genealógico de la historia, formado a partir de los síntomas de la plasticidad de los tiempos heterogéneos o "diferenciales del tiempo" ${ }^{8}$ y de la compleja sobreabundancia de montajes.

La productividad y revitalización que Didi-Huberman realiza del concepto de anacronismo aplicado a la imagen histórica permite, mutatis mutandis, indagar en la productividad y revitalización del anacronismo como procedimiento poético-dramatúrgico. Al seguir esta perspectiva analizaré la composición dramatúrgica de la imagen histórica y mítica de El Maruchito desarrollada por Rithner.

En términos de "estructura textual" 49 esta obra se compone de tres secciones que, desde mi visión, ratifican — sin caer en una filiación esencialista— su posible semejanza o asociación con la forma escritural del docudrama.

Primero, se registra un breve prólogo, narrado como una dedicatoria personal a uno de los actores del montaje de 1997, puntualmente, al actor Juan Queupán o Juan "el indio", quien a pocos meses del citado estreno teatral

45. Paul Ricoeur, La memoria, la historia, el olvido (Buenos Aires: Fondo de Cultura Económica, 20I3), 3II.

46. Georges Didi-Huberman, Ante el tiempo. Historia del arte y anacronismo de las imágenes (Buenos Aires: Adriana Hidalgo, 20II), 32.

47. Didi-Huberman, Ante el tiempo, 45.

48. Didi-Huberman, Ante el tiempo, 40.

49. García Barrientos, Cómo se comenta una obra de teatro. Ensayo de método, 48. 


\section{DOI: https://doi.org/10.22201/iie.18703062e.2021.119.2764}

352

MAURICIO TOSSI

sufre un hecho de extrema violencia policial, cargado de prejuicios raciales. En correlación con este dato biográfico y mediante una comparación implícita, este paratexto preliminar introduce una primera imagen histórico-documental, que será resignificada en el discurso ficcional, me refiero a la figura del joven Walter Bulacio, ${ }^{\text {so }}$ un símbolo nacional del abuso de las fuerzas del Estado en plena fase democrática.

En segundo lugar, podemos leer el corpus ficcional o texto teatral propiamente dicho, concebido en un extenso acto único, sin notaciones dramáticas divisorias y con una específica organización ficcional que expondré en párrafos posteriores.

Por último, hallamos un paratexto posliminar, con el título de "bibliografía”, en el que se declaran — con índices precisos— las numerosas fuentes (literarias, artístico-teatrales, historiográficas, periodísticas y testimoniales) que conforman los basamentos referenciales de la dramaturgia. Resulta necesario detenernos en esta tercera macrounidad del texto, por su singularidad notarial y por su "liminalidad"sr entre texto dramático y texto académico. En suma, la composición textual de la obra El Maruchito ofrece un mapa de referencialidades teórico-historiográficas que el lector podrá ejercer en su tarea de contrastación, es decir, en su intento de acceder a la ratificación o refutación de los datos empíricos expuestos como prueba de verdad, incluso, cuando el discurso elaborado posea argumentaciones míticas que no suelen ser contratextualizadas. No obstante, por medio de este recurso, se le garantiza al lector el derecho a ejercer su valoración fáctica — res factae - de los sucesos ficcionalizados o res fictae.

La relevancia de este compendio bibliográfico en el esquema general del texto se expresa en 3I fuentes y en cinco testimonios declarados. Esta contundente pulsión referencial remite a diversos niveles y grados de la organización ficcional de la dramaturgia de El Maruchito, sin embargo, en este estudio me

50. Bulacio fue asesinado por miembros de la Policía Federal en 199i. En el marco de una inestable democracia, la repercusión nacional e internacional del caso provocó diversos cambios comunitarios y legislativos.

5I. Para Dubatti, la liminalidad en los estudios escénicos contemporáneos implica el reconocimiento de las tensiones ontológicas del acontecer teatral, es decir, la "fronterización" de entidades tales como realidad/ficción, representación/presentación, historia/memoria o, en este caso, por su basamento morfológico, la disolución de los márgenes convencionales entre texto dramático y texto académico. Véase Jorge Dubatti, Teatro-matriz, teatro liminal (Buenos Aires: Atuel, 2016). 


\section{DOI: https://doi.org/10.22201/iie.18703062e.2021.119.2764}

APROPIACIONES HISTORIOGRÁFICAS DE LA DRAMATURGIA

centraré en la composición por rodeo anacrónico de la "imagen matricial" ${ }_{22} \mathrm{e}$ hipertextual del marucho, ${ }^{53}$ según el análisis comparativo de los libros y artículos recopilados por Rithner en su trabajo bibliográfico. Desde esta perspectiva, el autor construye, por un lado, una imaginería escénica de aquel paisanito en la Patagonia de principios del siglo xx a partir de las versiones histórico-míticas de Jorge Castañeda, ${ }^{54}$ Elías Chucair, 55 Pablo Fermín Oreja ${ }^{56}$ Nicasio Soria ${ }^{57}$ y Leandro Isidro Toledo. ${ }^{8}$ Por otro lado, su posicionamiento estético dialoga —de modo implícito - con el "juego sinérgico" postulado por Canal Feijóo para el teatro histórico y, con esto, ingresa tácitamente a una genealogía dramatúrgica que impugna las fronteras entre norte y sur.

Por consiguiente, la segunda sección o el corpus ficcional del texto puede, en términos estructurales, organizarse en cuatro macrosecuencias dramáticas que nos permiten objetivar los procedimientos utilizados por Rithner: I) introducción o prótasis con bases metateatrales, en la que se representa —en un tiempo diegético que es equivalente al vivido por el lector/espectador - a un grupo de artistas de radioteatro y circo criollo que tiene por fin la escenificación del relato mítico de El Maruchito; 2) ficcionalización de las luchas populares y anarquistas de principios del siglo xx en Buenos Aires, tangencialmente asociada

52. En la teoría de lo imaginario, esta noción implica un nivel de pregnancia textual, manifestado en la presencia subyacente de estructuras icónico-verbales que contribuyen a su afianzamiento. Entonces, "bajo el texto legible operan esquemas, figuras, arquetipos, que actúan como matrices de sentido y como operadores, conductores que hacen pasar un sentido universal a uno particular, o inversamente". Cita extraída de Jean-Jacques Wunenburger, Antropología del imaginario (Buenos Aires: Ediciones del Sol, 2008), 37.

53. En la cultura popular de la Patagonia y, según los marcos de referencia de la obra, un marucho es un niño o joven paisano que, durante los tránsitos comerciales y romerías sureńas que caracterizaron a gran parte del siglo xIX y principios del xx, trabajaba al servicio de los traperos, generalmente en condiciones de explotación. Por consiguiente, a lo largo del ensayo distinguiremos entre El Maruchito como una imagen mítico-histórica y El Maruchito (con cursivas) como la versión dramatúrgica de Rithner.

54. Jorge Castañeda, "El Marucho, leyenda rionegrina", Revista Huaico, núm. 3 (1985): 4.

55. Elías Chucair, El Maruchito: hacedor de milagros en la meseta patagónica (General Roca: Editorial de la Patagonia, 1985).

56. Pablo Fermín Oreja, Leyendas y tradiciones de Río Negro (Viedma: Dirección de Cultura de Río Negro, 1974), 38-44.

57. Nicasio Soria, Bueyes perdidos. Humor patagónico (General Roca: Editorial de la Patagonia, 1984).

58. Leandro Isidro Toledo, Historia de la fundación y progreso de General Roca (Bahía Blanca: Edición del autor, 1972). 


\section{DOI: https://doi.org/10.22201/iie.18703062e.2021.119.2764}

con las acciones ácratas en la Patagonia; 3) figuración dramatúrgica de Pedrito Farías (el marucho), es decir, el nudo central de la fábula; 4) figuración dramatúrgica de los emergentes de la cultura joven — junto con el afianzamiento de las fuerzas represivas del Estado- durante los años setenta, una secuenciación de síntesis escénica que promueve —-mediante un rodeo anacrónico- la enunciación de la siguiente tesis social: la "muerte de lo joven" opera como una cadena significante, sedimentada y altamente reproductiva en la matriz histórico-comunitaria de la región. Esta unidad de cierre conlleva a un desenlace circular, esto último, por su retorno al juego metateatral inicial.

La primera macrosecuencia, inscrita en las dimensiones metaficcionales ya indicadas, comienza con una extensa didascalia, en la que se señala: "La troupe de artistas convoca al público y lo atrae hacia la pista semicircular donde se contará la historia. Este espacio es una gran carpa circense sin lona que la cubra e iluminada con abundantes guirnaldas de luces de colores". ${ }^{59}$ En esta espacialidad, con evidentes reminiscencias de las prácticas escénicas populares, ${ }^{60} \mathrm{la}$ acción dramática se focaliza en la presentación de los distintos miembros de la Compañía Radioteatral La Balsa, compuesta por actores y actrices, cantantes, trapecistas, magos, titiriteros/as y, en particular, por una voz que operará como un actante de convergencia en todo el desarrollo de la obra: el Relator, quien con sus características intervenciones teatrales o publicitarias, sostenidas en las reconocibles convenciones retóricas del género, hilvana los diversos sucesos o microsecuencias.

Mediante estos recursos visuales, sonoros y metateatrales los personajes les proponen a sus espectadores representar una historia olvidada, pues, en aquella cartografía, "la memoria tiene olor rancio a veces" ${ }^{61}$ Ese olvido territorializado y estampado en un viento patagónico lacerante, se sustancia en el mito de El Maruchito. Al respecto, se dice: "Sopla el viento aquí en el Sur.../ Sopla y sigue lastimando/ porque mataron a un joven/ y el crimen no castigaron." ${ }^{62}$

59. Juan Raúl Rithner, "El Maruchito. Sangre y encubrimiento allí en las tierras del viento", en Antología del teatro rionegrino en la posdictadura, comp. Mauricio Tossi (Viedma: Universidad Nacional de Río Negro, 2015), 77.

6o. Una de las secciones bibliográficas que el texto teatral de Rithner incorpora es, precisamente, una destacada lista de libros y artículos sobre circo criollo argentino, teatro popular o biografías de actores directamente involucrados con estos géneros.

61. Rithner, "El Maruchito", 79.

62. Rithner, "El Maruchito", 8o. 
Sustentada en este juego metaficcional, la acción progresa hacia la segunda macrosecuencia enunciada. En esta instancia se apela al procedimiento que invade toda la diégesis teatral: un anacronismo sostenido en el "rodeo", esto es, como ya adelanté, un recurso que integra el proceso poético de la "rapsodización” descrita en Hacha y quebracho. En efecto, para Jean-Pierre Sarrazac, el híbrido montaje de fragmentos históricos o míticos especialmente asociado al drama contemporáneo remite, entre otras lecturas, a una dramaturgia polifónica o de "rebalse" de voces y entretejidos discursivos que hace del "rodeo"63 una estrategia operativa. Así, el rodeo es una herramienta para fustigar lo inmediato o la "tiranía de lo actual" y, desde allí, generar un desplazamiento, un desvío en el abordaje de la "promiscua realidad" ${ }^{64} \mathrm{El}$ teórico francés dice:

Porque se alejan lo más posible de su objeto, al cual sólo consideran de manera oblicua, porque le dan la espalda a esta "realidad" que, sin embargo, parecen enfocar, porque escapan completamente de lo que Tackels llamaría un "teatro del reflejo", las dramaturgias del rodeo plantean de una manera nueva - y en los únicos términos que nos parecen hoy aceptables_ la cuestión del realismo. De un realismo que se pondría él mismo en entredicho [...] un realismo heurístico, un realismo en busca no de realidad sino de verdad. $\mathrm{Y}$ aun esta verdad no es en ningún caso una verdad adquirida por adelantado ni una verdad revelada, sino una verdad siempre en camino. ${ }^{65}$

Esta oblicuidad sobre lo real se despliega en el anacronismo, dado que el fundamento de valor que le atribuimos a El Maruchito de Rithner, expresado en la ya citada premisa: "Sopla el viento aquí en el Sur.../ Sopla y sigue lastimando/ porque mataron a un joven/ y el crimen no castigaron", ${ }^{66}$ será abordada mediante el "rodeo" producido por la yuxtaposición de fragmentos espacio-temporales distintos y distantes, por sus desplazamientos y desvíos que convierten al mítico Pedro Farías en una alegoría de las persistentes jóvenes muertes.

En correlación con este dispositivo metateatral, la dramaticidad de la segunda macrosecuencia no inicia literal y directamente con el relato mítico de El Maruchito, por el contrario, se centra en la acción de los personajes Rosa,

63. Para un abordaje integral de esta noción, véase Sarrazac, Juego de sueño y otros rodeos, 13-27.

64. Sarrazac, Juego de sueño y otros rodeos, I6.

65. Sarrazac, Juego de sueño y otros rodeos, 22-23.

66. Rithner, "El Maruchito", 8 o. 


\section{DOI: https://doi.org/10.22201/iie.18703062e.2021.119.2764}

356

MAURICIO TOSSI

Negra y Floreal, tres jóvenes obreros que viven en un barrio popular de la ciudad de Buenos Aires durante las décadas de i910 y 1920. El recurso de aproximarse a lo cercano/propio mediante la desterritorialización o el deslizamiento hacia lo distante/extraño ratifica la estrategia de rodeo antes mencionada y, además, estimula al lector/espectador a un juego de asociaciones histórico-documentales sobre las condiciones laborales en la región de la Patagonia y su vinculación con la hegemónica capital del país.

$\mathrm{Al}$ igual que en Hacha y quebracho de Dargoltz, la pieza de Rithner conforma un collage dramatúrgico con múltiples fragmentos espacio-temporales, en los que la acción teatral se somete a la narración historiográfica con el propósito de generar la ya indicada pulsión referencial. Por consiguiente, el desarrollo escénico muestra determinados perfiles sociopolíticos del periodo, por ejemplo, vemos a Floreal, Negra y Rosa en el marco del sufragio universal, masculino-obligatorio y secreto, legalizado por el presidente Roque Sáenz Peńa en I9I2 y en la consecuente asunción en I9I6 de Hipólito Yrigoyen, un emblema del primer gobernante elegido por el voto popular. Sin embargo, estos personajes también transitarán por la desilusión ante la inaugural presidencia radical y, además, vivirán las masacres y represiones sobre los trabajadores organizados, en particular, sobre los adherentes a la FORA (Federación Obrero Regional Argentina). Por esto, una de las fuentes docudramáticas reconocibles es la "Marcha de los anarquistas", allí se dice: "Nuestros amos y señores / prometieron ayudarnos / pero en vez de mejorarnos / ¡nos mezquinan hasta el pan! / Parabaraba pam papam / Parabara pam pam / Pam papam." ${ }^{67}$

Los tres jóvenes obreros, junto con personajes-papeles definidos por el autor como "vecinos" serán las fuerzas dramáticas que representarán las luchas gremiales y sus correlativas confrontaciones con los sectores económico-dominantes, principalmente con la Liga Patriótica Argentina. ${ }^{68}$ Estos índices temporales se observan en la intertextualidad con premisas ultraderechistas de uno de sus fundadores, el político y escritor Manuel Carlés o, también, de su correligionario Luis Dellepiane, incluso, se alude a la traición de síndicos colaboracionistas. Así, estos personajes vivirán la implantación de la Ley núm. 7029 o Ley

67. Rithner, "El Maruchito", 83.

68. Se alude a una agrupación parapolicial creada en I9I8, con el objeto de perseguir, reprimir y asesinar a anarquistas y sindicalistas, aunque su acción de choque también se extendió a la comunidad judía y otras fracciones sociales contrarias a los ideales de las derechas liberales, católicas y nacionalistas. 
de Defensa Social —utilizada para la prohibición de ingreso al país, encarcelamiento y deportación de anarquistas u otros extranjeros con activismo político- y la muerte de sus compañeros en el contexto de la llamada "Semana trágica” de 1919, al mismo tiempo que los jóvenes obreros porteños comienzan a leer en la prensa disidente las briosas reacciones de los huelguistas patagónicos durante la llamada "Patagonia rebelde" ${ }^{69}$

La estrategia del rodeo, desarrollada en la perspectiva metateatral y en su efecto de extrańamiento, en la fusión de fragmentos temporales anacrónicos, como así también en la barroca proliferación de referencias y citas textuales con bases historiográficas (nombres propios de síndicos, empresarios, militares; localizaciones geográficas connotativas; extractos de canciones de protesta anarquistas o del manifiesto socialista; reseñas periodísticas de los sucesos históricos; entre otros) le permite a Rithner argüir tangencialmente una causalidad pragmática o empírica a la acción escenificada: las paupérrimas y sistemáticas condiciones de trabajo registradas en la Patagonia. Esta interpretación constituye una reescritura materialista o contraidealizante del mito de El Maruchito, dado que el autor responde con realemas poético-objetivistas a la pregunta: ¿por qué un joven marucho, un niño changador explotado, es asesinado en las circunstancias descritas por el relato popular? Así, se comienza a entretejer en la estructura ficcional la isotopía que, por su redundancia pedagógica, contribuirá a la enunciación de la tesis social arriba señalada.

En suma, lo que en un determinado nivel sintáctico del relato puede relacionarse a las estrategias de rodeo ya comentadas, en un grado de profundidad morfotemático el texto genera un nexo — con causalidad histórica y documental- entre las protestas sociales o revueltas anarquistas de principios del siglo xx y la interpretación materialista de las causas del asesinato del marucho rionegrino.

Entre la primera y la segunda macrosecuencias detalladas, las tensiones dramáticas y metadramáticas juegan un papel preponderante, pues las rupturas y los entrecruzamientos entre los dos planos aportan a la hermenéutica de la experiencia estética descrita. Al tener en cuenta su "focalización", los personajes Relator y Operador (inscritos en la lógica del argumento radioteatral)

69. En referencia a los libros escritos por Osvaldo Bayer a partir de 1972, sobre las movilizaciones y huelgas anarcosindicales realizadas en los territorios de Santa Cruz entre I920 y 1922, las que a su vez provocaron miles de despidos, persecuciones y fusilamientos perpetrados por terratenientes, fuerzas oficiales o paramilitares. 


\section{DOI: https://doi.org/10.22201/iie.18703062e.2021.119.2764}

358

MAURICIO TOSSI

son quienes ejecutan estos nexos entre una "perspectiva externa" (objetiva y con efecto de extrañamiento) y una "perspectiva interna" (subjetiva e ilusionista). ${ }^{70}$ De este modo, la ficcionalización de los conflictos obreros en Buenos Aires es persistentemente "distanciada" por una acción del orden metateatral, entre otros, por la publicidad de un jabón de lavar, por un texto lírico en alusión a las tierras del sur o la sonorización del viento patagónico según los códigos de la radiofonía e, incluso, por el recitado de una poesía auspiciada por un restaurante de la ciudad General Roca (residencia efectiva del autor) la que, de manera puntual, tiene a El Maruchito como eje temático y responde a la autoría de Elías Chucair, es decir, una de las fuentes bibliográficas del drama.

La tercera macrosecuencia incluye, como ya se adelantó, el tema medular de la obra, compuesto por la singular reescritura teatral del mito sobre El Maruchito, según las reconfiguraciones escénicas que el dramaturgo propone en función de las fuentes bibliográficas declaradas. En efecto, siguiendo el encuadre metadiegético mencionado antes, se aclara: "RELATOR: El Marucho que aquí ven / no es de Rithner todo entero... / Tiene algo de Chucair, / de Oreja, Bajos y Soria, / de Castañeda y Toledo... / Y algo nos toca, y queremos dedicarlo a nuestro pueblo...". ${ }^{1}$

La contrastación entre la dramaturgia de Rithner y las obras referenciadas de Chucair, Oreja y Castañeda permite reconocer una determinada relación hipotextual o "dinámica intratextual" 72 que, lógicamente, conlleva a "determinantes hipertextuales"73 asociados con la imagen del marucho elaborada por el autor teatral rionegrino. Esta dinámica compositiva se observa en los siguientes aspectos estructurales:

a) La coincidencia en la identidad del joven Pedro Farías, caracterizado como un niño o adolescente huérfano, abandonado en la estepa de la Línea Sur rionegrina (paraje Bajada Colorada) y alienado a las formas de vida de los traperos, ejerciendo el único papel posible para sobrevivir, el de peón por comida y traslado.

b) La coincidencia en la dimensión temporal, pues tanto Chucair como Castañeda ubican la acción en I916 o I919, respectivamente. Este

70. García Barrientos, Cómo se comenta una obra de teatro, 252-255.

7I. Rithner, "El Maruchito", 80.

72. Wunenburger, Antropología del imaginario, 35 .

73. Wunenburger, Antropología del imaginario, 38. 
periodo plantea, además, una sincronía entre los episodios escénicos de la segunda macrosecuencia (las acciones y relatos sobre los huelguistas capitalinos o sureños) y el suceso mítico.

c) La coincidencia actancial, en tanto las distintas matrices textuales analizadas exponen al niño como un changador del trapero Onofre Parada, quien asesina al marucho con dos puñaladas por desobedecer una explícita prohibición: no tocar su guitarra. De este modo, tanto la narrativa de Chucair y Oreja, como la poesía de Castañeda y la dramaturgia de Rithner concuerdan en este particular yerro mítico, cercano — por su funcionalidad literaria - al pecado de hybris aristotélico.

d) La coincidencia semántico-imaginaria, es decir, se asevera la resignificación geocultural de El Maruchito como un emergente de la religiosidad popular de la norpatagonia, en particular, a partir de 1924, cuando su tumba comienza a ser venerada por los lugareños, mediante flores, cartas y placas depositadas en su ermita, las que manifiestan actos de fe y agradecimiento.

A pesar de estas semejanzas y reciprocidades entre las fuentes hipotextuales y la reescritura escénica, Rithner incorpora al relato nuevos componentes, que otorgan a la fábula una mayor densidad y consistencia teatral.

En primer lugar, esta "reanimación hermenéutica" 74 del mito popular le ofrece al yerro trágico del protagonista una motivación o, en términos actanciales, un "destinador" singular, esto es, tomar la guitarra vedada con el propósito de entonar la única canción que le permite al niño rememorar a su madre fallecida. La citada canción versa: “¿En qué nos parecemos, / tú y yo, a la nieve... / Tú, en lo blanca y galana; / yo, en deshacerme...". ${ }^{75}$ A su vez, desde la perspectiva del Tropero, la prohibición es justificada por ser la guitarra un símbolo de la infidelidad amorosa vivida. Estas significaciones completan los vacíos o lagunas narrativas observables en las versiones de Chucair, Castañeda y Oreja.

En segundo lugar, la versión teatral introduce dos nuevos personajes en el relato: uno, el "artista", ayudante del protagonista, mediante el cual se recupera la figura histórica de los payadores o narradores populares, por ser un peón más

74. En la teoría de lo imaginario, esta noción alude a uno de los procedimientos utilizados en las transformaciones de la dinámica intratextual y las determinaciones hipertextuales, fundamentalmente centrada en la reactivación semántica del relato en un nuevo marco histórico-cultural. Véase Wunenburger, Antropología del imaginario, 42.

75. Rithner, "El Maruchito", II4. 


\section{DOI: https://doi.org/10.22201/iie.18703062e.2021.119.2764}

de la cuadrilla, pero con la capacidad de recitar, actuar o cantar en el marco de los legendarios fogones de las tropas de carros sureños. Otro, la "Mujer de Negro", figuración de la muerte que remite a los personajes jeroglíficos o alegóricos de las tragedias simbolistas, por ejemplo, a las obras de Federico García Lorca. Esta personificación tiene a su cargo, consecuentemente, la prolepsis del final funesto.

A partir de la muerte de El Maruchito, la estructura ficcional ingresa a la cuarta y última macrosecuencia dramatúrgica enunciada, en la que se consolida y radicaliza la principal estrategia diegética planteada por Rithner: focalizar en la potencialidad anacrónica de la imagen-matriz del peoncito ultimado y, luego, convertido en un emblema de la religiosidad popular.

Esta cuarta macrosecuencia dramática es, básicamente, la síntesis del fundamento de valor de la obra, formulado mediante el anacronismo y la "transfiguración barroca” ${ }^{6}$ de la figuración de El Maruchito. En términos formales, la pieza intensifica el énfasis en los componentes diegético-historiográficos por encima de la acción dramática, al virar hacia lo que podríamos familiarizar con un "drama de estaciones" según la tradición dramatúrgica de Strindberg y que, sin duda, impactó en el teatro rioplatense moderno de la década de 1960 y fases subsiguientes.

De este modo, la yuxtaposición e intersección de tiempos heterogéneos y discontinuos, con el fin de insertar o incrustar en esas temporalidades discordantes la imagen-matriz de El Maruchito, genera una "imagen-otra" del peón asesinado, es decir, se construye una "otredad temporal" que evidencia la persistente violencia institucional y estatal sobre los cuerpos utópicos, en este caso, "el joven" de los años dictatoriales y posdictatoriales. Esta tesis social se objetiva dramatúrgicamente en el devenir de las "estaciones", organizadas de manera cíclica y con carácter ritual, a saber: el personaje artista — quien intentó sin éxito salvar al protagonista- traslada el cuerpo yaciente del joven por diversos espacios dramáticos, colocándolo en cruz y propiciando una relación de semejanza o analogía histórica con otras "muertes jóvenes".

Mediante esta ritualización anacrónica, la indicada macrosecuencia se compone de cuatro "estaciones" breves, que son permanentemente hilvanadas y extrañadas por la actuación de los personajes Relator y Operador, quienes a la

76. Me refiero a otro de los procedimientos que permiten reconocer las transformaciones entre la dinámica intratextual y la determinación hipertextual, puntualmente: "procedimiento de tipo 'barroco', en el que una formación mítica se ve transformada por una reescritura lúdica que obra por medio de inversiones, parodias o trompe-l'aeil". Cita extraída de Wunenburger, Antropología del imaginario, 43. 
vez mantienen el régimen metateatral con la inclusión de publicidades radiales y/o definiciones historiográficas sobre la evolución sincrético-religiosa de El Maruchito.

La primera estación inicia en los convulsionados años setenta, con los asesinatos de jóvenes en la denominada Masacre de Ezeiza, esto último en el marco del retorno de Juan Domingo Perón luego de i8 años de proscripción. Con esta sucinta unidad de acción, se introduce — de manera tangencial — la imagen de los jóvenes detenido-desaparecidos durante la dictadura cívico-militar iniciada en 1976. La segunda estación remite a 1983, en este caso, El Maruchito cede su figuración — por transposición alegórica — a los miles de jóvenes que reclaman la reapertura democrática y, al mismo tiempo, conforman un activismo utópico que será posteriormente reprimido. La tercera estación se inscribe en I99I, ahí el peoncito rionegrino es la imagen-matriz para figurar una paradigmática muerte joven: el asesinato de Walter Bulacio por la Policía Federal, una institución que reproduce en tiempos de democracia las prácticas de control y detención dictatoriales. Finalmente, la última estación reactiva la imagen de Omar Carrasco, el conscripto de 20 años que ingresó en I994 al Grupo de Artillería I6I del Ejército Argentino, en la ciudad de Zapala. Allí, el joven fue torturado, ultimado, desaparecido y, luego, en virtud de los incesantes reclamos comunitarios, fue de manera clandestina "reaparecido" y declarado muerto por razones naturales. El reconocimiento de una persistente metodología terrorista en la disciplina militar provocó un cimbronazo en las fuerzas armadas de la incipiente democracia, a tal punto que el llamado "Caso Carrasco" simbolizó la derogación del Servicio Militar Obligatorio en todo el territorio nacional.

La atmósfera ritual, repetitiva y circular, de las cuatro estaciones finaliza con otra imagen utópica, la de una joven en tiempo presente que enciende una vela y la coloca frente al cuerpo de El Maruchito, el cual, en esta instancia dramatúrgica, condensa de manera barroca y sobrecargada las figuras de los jóvenes en tiempos dictatoriales y posdictatoriales, así como las representaciones históricas de Bulacio y Carrasco. En este gestus final, la muchacha reclama un urgente ejercicio de memoria histórica, el que debemos circunscribir al año de escritura y estreno de esta obra, es decir, 1997, etapa en la que la República argentina aún transita por un "olvido jurídico impuesto". ${ }^{77}$ En suma, la transfiguración anacrónica y barroca propuesta por Rithner se sintetiza en un

77. Véase Elizabeth Jelin, "Los derechos humanos entre el Estado y la sociedad", en Nueva 


\section{DOI: https://doi.org/10.22201/iie.18703062e.2021.119.2764}

ideologema shakesperiano, al servicio de la redundancia pedagógica de la tesis arriba expuesta, dice: "Si la clemencia absuelve a los que matan, participa del crimen, la clemencia." ${ }^{8}$

\section{Ideas finales}

De las múltiples relecturas o revisitas poéticas que los dramaturgos argentinos han realizado en el marco de la posdictadura, en este estudio se ha particularizado en la regionalización crítica del docudrama en el noroeste y en la Patagonia (1983-1997), mediante el reconocimiento y examen procedimental de los núcleos historiográficos que propiciaron una determinada productividad dramatúrgica. Así, los casos de Hacha y quebracho y El Maruchito permitieron la descripción de una específica "pulsión referencial" con base en la historia socioeconómica y mítica del norte y el sur. A pesar de sus fronteras (materiales y simbólicas), se evidencia una solidaridad poético-organizacional entre ambas regiones, al optar por la resignificación de procedimientos docudramáticos tales como la contratextualidad y el rodeo anacrónico que, entre otros efectos, contribuyen a la promoción de los "trabajos de la memoria", ${ }^{79}$ tamizados en un locus de enunciación diferencial para el abordaje de las interrogaciones comunitarias sobre los sentidos del pasado reciente. En suma, a partir de la lectura interregional de estas creaciones dramatúrgicas se objetiva un programa estético-ideológico que irriga a ambas regiones: la singular y territorializada función memorística del teatro en el marco de los debates sobre las nuevas reconfiguraciones del sujeto democrático en el país. De este modo, la relación entre historia y memoria deviene, por los resultados obtenidos en este artículo, un nodo poético proactivo, el cual sin duda argumenta a favor de un futuro proyecto de investigación comparado. ${ }^{80}$

historia argentina. Dictadura y democracia 1976-200I, ed. Juan Soriano (Buenos Aires: Sudamericana, 2002), 505-557.

78. Rithner, "El Maruchito", I22.

79. Véase Elizabeth Jelin, Los trabajos de la memoria (Madrid: Siglo XXI, 2002).

8o. Para conocer algunos recientes y provisorios avances de esta línea de investigación, véase Mauricio Tossi, "Figuras autoficcionales de la 'memoria herida' en la dramaturgia argentina posdictatorial”, Letral. Revista Electrónica de Estudios Transatlánticos de Literatura, núm. 23 (2020): 89-II7. 


\section{¿Qué es la ópera? Una tipología general de ideas filosóficas}

\section{What is Opera? A General Typology of Philosophical Ideas}

Artículo recibido el 23 de marzo de 2020; devuelto para revisión el 4 de octubre de 2020; aceptado el II de noviembre de 2020; https://doi.org/IO.2220I/iie.I8703062e.202I.II9.2765

Daniel Martín Sáez Universidad de Oviedo, daniel.martins@uam.es, https://orcid. org/00oo-0002-6780-5220

Líneas de investigación Filosofía; musicología; historia de la ópera; historia de la música.

Lines of research Philosophy; musicology; history of opera; history of music.

Publicación más relevante "Estética, musicología y secularización. El mito del nacimiento de la ópera en la historiografía del último siglo", Resonancias 24, núm. 47 (2020): 39-58.

Resumen Desde su nacimiento a finales del siglo XvI, se han escrito muchas teorías sobre la ópera desde una perspectiva histórica, poética, musicológica, estética, política, entre otras. Sin embargo, no ha existido ningún intento sistemático por organizar estas teorías y plantear la pregunta fundamental: ¿qué es la ópera? Se mostrará que el término “ópera” responde a una idea filosófica, que desborda a cualquier disciplina positiva. De hecho, no existe una idea de ópera, sino varias, algunas de ellas contradictorias entre sí. En este artículo presento una tipología de ideas con base en tres criterios lógicos, que he obtenido tras analizar los propios materiales: la distinción sujeto/objeto, la distinción sincrónico/diacrónico y la distinción singular/plural. Esto ya enseña mucho sobre nuestra forma de entender la ópera, pero también nos obliga a preguntarnos si estas ideas son adecuadas para comprender el género.

Palabras clave Filosofía; ópera; tipología; taxonomía; sujeto; objeto.

Abstract Since its birth at the end of the I6th century, many theories have been written about opera from a historical, poetic, musicological, aesthetic, political and other points of view. However, there has been no systematic attempt to organize these theories and to ask the more basic question: what is opera? We will show that the term "opera" responds to a philosophical idea, beyond any positive discipline. In fact, there is no one idea of opera, but several, some of them contradictory to each 
other. In this article we present a typology of ideas attending to three logical criteria, which we have obtained after analyzing the materials themselves: the subject/object distinction, the synchronic/diachronic distinction and the singular/plural distinction. This teaches us a lot about our understanding of opera, but it also forces us to ask ourselves if these ideas are adequate to understand the genre.

Keywords Philosophy; opera; tipology; taxonomy; subject; object. 